\title{
Use of mineral licks by mammals in areas of the Amazonia with no hunting pressure
}

\author{
Patricio Macas-Pogo ${ }^{1 *}$, and María Cristina Osorio Sánchez ${ }^{1}$ \\ ${ }^{1}$ Ministerio del Ambiente, Agua y Transición Ecológica del Ecuador, Parque Nacional Yasuní, Programa de Reparación Ambiental \\ y Social (PRAS). Av. Amazonas N 24-198, 170524, Quito. Pichincha, Ecuador. Email: patomactkd@hotmail.com (PM-P), cris.oso- \\ rio98@gmail.com (MCOS). \\ * Corresponding author
}

\begin{abstract}
Mineral licks are areas where several species of animals, including mammals, converge to consume water and soil as a mineral supplement. Certain mammal species are an important source of protein in the diet of indigenous communities. Many of these species are under hunting pressure and their populations have been seriously affected. The purpose of this study was to determine the species of large and medium-sized mammals that use three open mineral licks in the area of the Kichwa Añangu community, within the Yasuní National Park, where hunting used to take place. We calculate the capture frequency for the visiting species and the richness, composition, and similarity of the assemblages recorded in the mineral licks during two climatic seasons of the year (higher rainfall vs. lower rainfall). We installed a single camera trap station (CTS) at each mineral lick during three sampling periods in 2018. In each period, all cameras operated 24 hours a day for 30 to 40 days and were set to capture three photographs upon sensor activation, with 60-second intervals between consecutive activations. With a total sampling effort of 249 days/trap, we obtained 645 photographs and 398 grouped records of 16 species. We recorded $95.2 \%$ of the expected richness according to the Chao1 estimator $(S=16.8)$. The species with the highest capture frequency were: Mazama zamora (FC =62.2), Tayassu pecari ( $F C=35.7)$, Tapirus terrestris ( $F C=28.9)$, and Pecari tajacu ( $F C=8.0)$. ECT-1 and ECT-2 captured 11 species each, and ECT-3 captured nine species. There were no significant differences in the species composition between the three mineral licks or between climatic seasons. Our results show that the focal mineral licks studied attract a rich mammalian fauna, which likely points to the success of the government regulation of wildlife trafficking and the application of sustainable tourism practices in the Añangu community.
\end{abstract}

Los saladeros son áreas donde convergen varias especies de animales, entre ellos mamíferos, para el consumo de agua y suelo como suplemento mineral. Entre los mamíferos que los visitan se incluyen especies que constituyen una fuente importante de proteína para la dieta de las comunidades indígenas. Las poblaciones de varias de estas especies han sido seriamente afectadas por la cacería. El propósito de este estudio fue conocer las especies de mamíferos grandes y medianos que usan tres saladeros abiertos que se encuentran en el área de la comunidad Kichwa Añangu dentro del Parque Nacional Yasuní, donde antes se realizaba cacería. Se determinaron sus frecuencias de captura, riqueza de especies, así como la composición y similitud de los ensamblajes registrados en los distintos saladeros y temporadas, una con mayor y otra con menor pluviosidad. Realizamos tres periodos de muestreo durante el año 2018 usando una estación de cámara trampa (ECT) simple en cada saladero. En cada periodo las cámaras permanecieron activas las 24 horas, durante 30 a 40 días, y fueron programadas para capturar tres fotografías al activarse el sensor, con intervalos de 60 segundos entre activaciones consecutivas. Con un esfuerzo total de muestreo de 249 días/ trampa obtuvimos 645 fotografías, con 398 registros agrupados de 16 especies. Se logró registrar un $95.2 \%$ de la riqueza esperada según el estimador Chao1 ( $\mathrm{S}=16.8$ ). Las especies con mayor frecuencia de captura fueron: Mazama zamora $(\mathrm{FC}=62.2)$, Tayassu pecari (FC $=35.7)$, Tapirus terrestris $(F C=28.9)$ y Pecari tajacu $(F C=8.0)$. Las ECT-1 y ECT-2 presentaron 11 especies cada una, la ECT-3 presentó 9 especies. No existieron diferencias significativas en la composición de especies entre los tres saladeros o entre temporadas. Nuestros resultados ponen en evidencia la riqueza de mamíferos que usan los saladeros como una fuente de minerales. Esto muy probablemente refleja el éxito de la regulación por parte del gobierno para el control de tráfico de vida silvestre y de la aplicación de las prácticas de turismo sostenibles en la comunidad Añangu.

Keywords: Añangu; camera trap; capture frequencies; conservation; Ecuador; richness; sustainable tourism; Yasuní.

(c) 2021 Asociación Mexicana de Mastozoología, www.mastozoologiamexicana.org

\section{Introduction}

It is very common to observe mammals and birds consuming fragments of soil from certain forest sites where they live, a phenomenon known as geophagy (Diamond et al. 2008; Gilardi et al. 1999; Setzl et al. 1999). Such sites are known as mineral licks or in the Neotropics as saladeros (Voigt et al. 2007), salt licks (Tracy and Mc Naughton 1995), or natural mineral licks (Emmons and Stark 1979), as they contain mineral salts of sodium, calcium, potassium, or iron (Emmons and Stark 1979; Klaus and Schmid 1998; Lizcano and Cavalier 2004; Montenegro 2004; Mah- aney et al. 2005; Link et al. 2012). Mineral licks can be classified as "open", "wall" or "caves", according to their characteristics (Montenegro 2004).

The mammals recorded visiting these mineral licks include chiropters, rodents, primates, and ungulates. In the case of birds, species of the orders Galliform (chickenlike birds locally known as pavas), Columbiform (pigeons), and in large numbers Psitaciform (parrots) have been recorded (Izawa 1993; Krishnamani and Mahaney 2000; Brightsmith 2004; Montenegro 2004; Voigt et al. 2007; Bravo et al. 2008; Tobler et al. 2009; Blake et al. 2010; Link et al. 2011; Link et al. 2012). 
It has been proposed that geophagy represents a supplementary source of minerals (Davies and Baillie 1988; Klaus and Schmid 1998) that help reduce the absorption of toxins from food (Kreulen 1985; Diamond et al. 2008; Gilardi et al. 1999). It is also thought that geophagy allows ingesting antacid agents to regulate gastric $\mathrm{pH}$ (Davies and Baillie 1988). Soil consumption varies according to the species, geography, and climate (Davies and Baillie 1988; Setz 1999; Blake et al. 2010; Blake et al. 2011).

The Yasuní National Park, located in the Orellana and Pastaza provinces in the Ecuadorian Amazon region, is home to the Kichwa and Waorani indigenous peoples (Licona et al. 2011). For these communities, subsistence hunting is a primary activity to obtain protein from the consumption of prey such as monkeys and peccaries (Blake et al. 2013). However, overhunting, in addition to the illegal trade in wildlife facilitated by roads built by oil companies (Bass et al. 2010), has led to the decline of animal populations in the forest and, thus, in mineral licks near these communities (Suárez et al. 2009; Espinosa and Salvador 2017; Blake et al. 2013).

Hunting has a greater impact on mammals than birds, likely because the selective hunting of larger species (Benitez-López et al. 2017). Decades ago, in the Kichwa Añangu community located on the Napo River banks within the Yasuní National Park, wildlife was being overhunted. However, when its decline was noted, a tourism project was launched in 1998 as an alternative for socio-economic development. The book of the History of the Añangu Community states that the commitment to tourism is also a response to the exploitation of the Amazon for oil extraction (Renkert 2019). Another initiative implemented afterward as a community policy was the discontinuation of illegal wildlife hunting and trafficking to allow the recovery of wildlife populations. As a result, after 20 years, there is an evident recovery of landmark wildlife species, such as giant otters, jaguars, and large primates (Suárez and Zapata 2019).

The present work documented the species of large and medium-sized mammal species using three mineral licks in the Kichwa Añangu community area, using camera traps. In addition, capture frequencies and species composition in different climatic seasons were determined.

\section{Methods}

Study Area. Camera trap stations (ECT, for its acronym in Spanish) were installed in three open mineral licks of brown, marshy clay soils with a thin layer of decaying litter. ECT-1 $\left(0^{\circ} 32^{\prime} 15.818^{\prime \prime},-76^{\circ} 24^{\prime} 16.083^{\prime \prime}\right)$ was installed in a mineral lick of approximately $260 \mathrm{~m}^{2}$, ECT2 $\left(-0^{\circ} 31^{\prime} 58.068^{\prime \prime}\right.$, $\left.-76^{\circ} 22^{\prime} 11.360^{\prime \prime}\right)$ in one of approximately $200 \mathrm{~m}^{2}$, and ECT-3 $\left(0^{\circ} 31^{\prime} 14.939^{\prime \prime}, 76^{\circ} 21^{\prime} 4.527^{\prime \prime}\right)$ in one of about $150 \mathrm{~m}^{2}$. The three mineral licks were located within the territory of the Kichwa Añangu community in the Yasuní National Park, province of Orellana (Figure 1); this area is part of the Yasuní Biosphere Reserve, considered one of the most biodiverse regions worldwide (Bass et al. 2010). The study area is mainly covered by periodically flooded forests (varzea), non-flooded dryland forests, and marshlands where the buriti palm (Mauritius flexuosa) predominates. It is located within the Eastern Tropical zoogeographic region (Albuja et al. 2012), characterized by a humid tropical climate (Unesco 2010). According to the Nuevo Rocafuerte monitoring station of the National Institute of Meteorology and Hydrology (INHIM), in 2018, the total precipitation was approximately $3,300 \mathrm{~mm}$ and the average monthly temperature was $26.1^{\circ} \mathrm{C}$. Precipitation is concentrated between February and July and decreases the rest of the year, ranging between 2,881 mm and 3,942 mm (Pitman 2000; Albuja et al. 2012; Blake et al. 2012),

Sampling Design. We visited the mineral licks on three occasions to install the ECTs, which remained in operation for three periods of 30 to 40 days. The first period spanned from February to March, the second from June to July, and the third from November to December 2018; we recorded information from nine camera traps in total, three for each period.

The three mineral licks were georeferenced with a Garmin Oregon 650t GPS (Garmin Ltd.); the distance between them ranged from 2.5 to $6.4 \mathrm{~km}$. Each ECT was equipped with one camera trap (Bushnell Trophy Cam HD, Aggressor model, Bushnell Corporation). Cameras were attached to tree trunks at the edge of each mineral lick, at a height of 0.5 to $0.75 \mathrm{~m}$ above the ground, and were oriented toward wildlife trails. These were set to capture three photographs each time the motion sensor was activated, with a 60-second interval between activations. The sampling effort varied between 61 and 98 camera trap days between mineral licks. The number of camera trap days was estimated from the time the camera started operating until the last image was captured (based on the date and time stamped on the pictures).

Data Analysis. The images captured were entered and processed in the Wild.ID software (https://www.wildlifeinsights.org/team-network). Based on the criteria proposed by Tobler et al. (2009), Blake et al. (2011), and Link et al. (2012), "independent" records were those images captured consecutively from clearly distinguishable individuals or individuals of the same species captured by the same camera within a 60-minute interval.

To assess the completeness of the species inventory, the species richness estimators Chao 1 and ACE were calculated for each mineral lick and a species accumulation curve was constructed for the data set using the EstimateS 9.1.0 program (Colwell and Coddington 1994; Colwell 2013). To determine whether this variation influenced the estimation of species richness between mineral licks as well as between seasons, an analysis was performed with rarefaction curves interpolated to the smallest sample (Krebs 1989; Colwell et al. 2012) using the program Past 3.03 (Hammer et al. 2001). The Jaccard similarity index was also calculated to evaluate the similarity of species composition between mineral licks as well as between climatic seasons (Moreno 2001). 
The capture frequency ( $F C$, for its acronym in Spanish) of each species was calculated by dividing the number of capture events by species for the sampling effort (number of camera trap days) in each mineral lick and climatic season and multiplying by 100 to facilitate comparisons with similar studies (Blake et al. 2011; Blake et al. 2013).

Capture frequency (FC) patterns were compared graphically through rank-abundance curves (Whittaker's plots) based on Magurran (2004). The vertical axis measured capture frequencies and the horizontal axis measured the range of species recorded in each mineral lick (ECT), the total number of species of the whole study, and the number of species by climatic season.

\section{Results}

A total sampling effort of 249 camera trap days yielded 645 images, of which 398 were independent records of 16 species in 11 families and seven taxonomic orders. The number of independent records per mineral lick varied between 112 and 159, with 11 species recorded in the first and second mineral licks and 9 in the third (Table 1). The taxonomic order with the highest number of records was Rodentia, with three families and four species (Table 2).

Observed Species - Species Richness Estimates. A total of 16 species $\left(\mathrm{S}_{\mathrm{obs}}\right)$ were recorded, accounting for $95.2 \%$ of the figure estimated with Chao1 $(S=16.8)$ and $85.6 \%$ of the figure estimated with ACE $(S=18.7)$. Therefore, a repre-
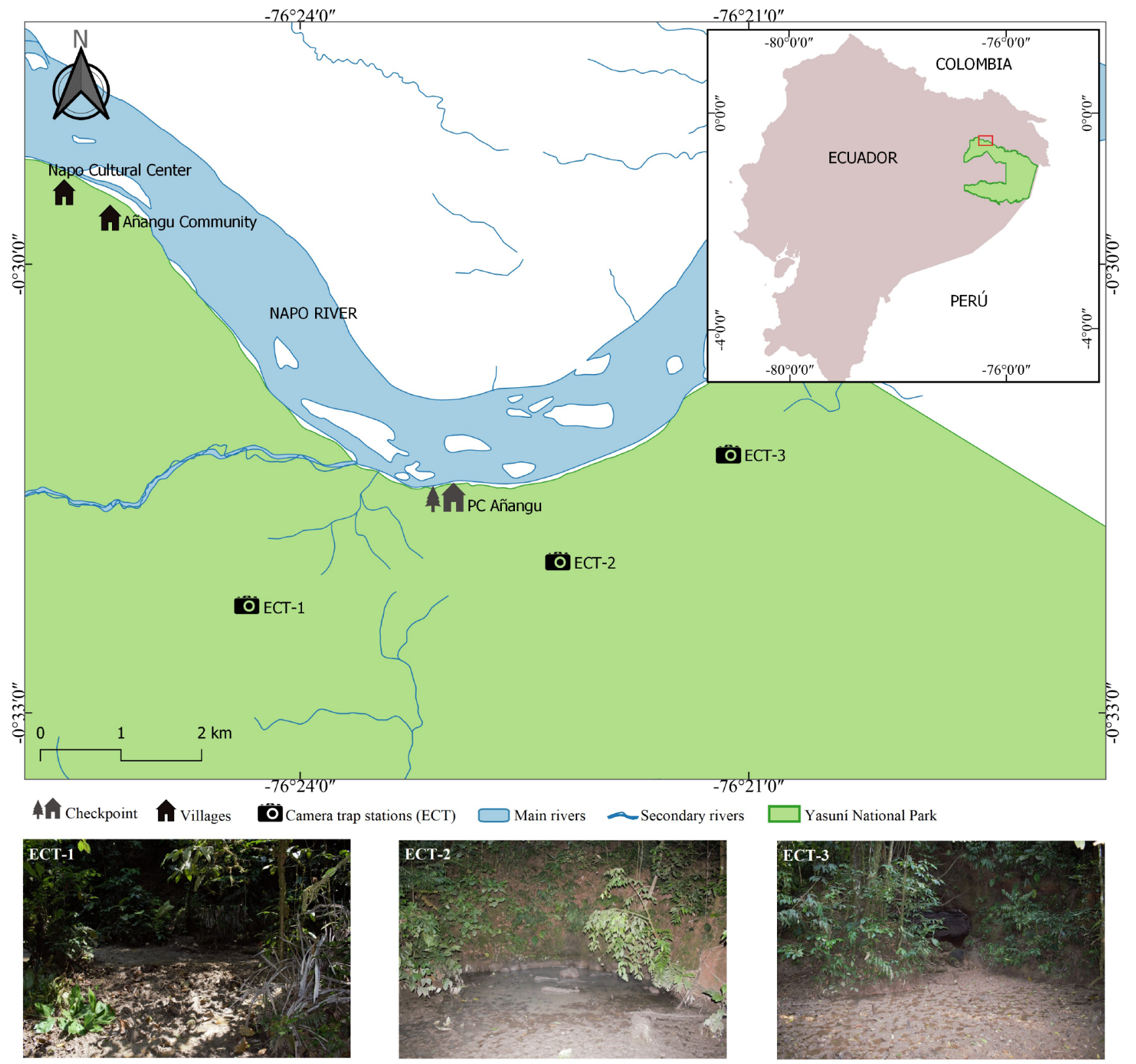

Figure 1. Map of the study area showing the location of the camera trap stations (ECT) in the three mineral licks, Kichwa Añangu community village, and Yasuní National Park checkpoint. 
sentative sample was obtained in general terms. However, in ECT-1, the recorded species amounted to $42.5 \%$ of the Chao1 estimate $(S=25.9)$ and $28.6 \%$ of the ACE estimate $(S=38.5)$. In contrast, ECT-2 recorded $100 \%$ of the Chao1 estimate $(S=11)$ and $94.8 \%$ of the ACE estimate $(S=11.6)$. ECT-3 recorded $75.6 \%$ of the species estimated by Chao 1 $(S=11.9)$ and $70.9 \%$ of the expected species according to ACE $(S=12.7$; Table 1).

Table 1. Camera-trap data in three mineral licks located in the Yasuní National Park, Kichwa Añangu community. Trap Camera Station (ECT).

\begin{tabular}{lrrrr}
\hline & ECT-1 & ECT-2 & ECT-3 & Total \\
\hline Camera trap days & 61 & 98 & 90 & 249 \\
No. of captures & 303 & 137 & 205 & 645 \\
Species richness $\left(\mathrm{S}_{\text {obs }}\right.$ ) & 11 & 11 & 9 & 16 \\
Number of independent records & 159 & 112 & 127 & 398 \\
Chao 1 & 25.9 & 11.0 & 11.9 & 16.8 \\
ACE & 38.5 & 11.6 & 12.7 & 18.7 \\
\hline
\end{tabular}

Capture Frequency of Mammalian Species. The species recorded most frequently over the three sampling periods were the red brocket (Mazama zamora; 155 independent records, FC $=62.2$ ), white-lipped peccary (Tayassu pecari; 89 independent records, FC $=35.7$ ), South American tapir (Tapirus terrestris; 72 independent records, $F C=28.9$ ), and collared peccary (Pecari tajacu; 20 independent records, $F C=8.0$ ). The species with the lowest number of records were the collared anteater (Tamandua tetradactyla), whitefronted Capuchin (Cebus yuracus), and green acouchi (Myoprocta pratti), with one independent record $(F C=0.4)$ in each case (Table 2 ).

The most frequent species in the three mineral licks were M. zamora, T. terrestris, T. pecari, and A. seniculus. These species obtained different capture frequencies in each ECT, thus attaining a different rank. These were the most abundant species and were relatively easy to capture with camera traps; the exception was $A$. seniculus, which appeared among the dominant species only in ECT-2 (Figure 2).

Rarefaction and Interpolation. It was found that by interpolating to the smallest number of independent records (112 records), ECT-2 was the mineral lick with the highest number of species $(S=11)$. This indicates that species richness in this site was significantly higher relative to ECT-3 $(S=8.6)$ under the same number of records since the confidence intervals did not overlap. However, the confidence intervals of ECT-1 $(S=9.2)$ overlapped with those of the other sites, so differences were non-significant (Figure 3).

Climate Temporality: Rarefaction and Interpolation, Capture Frequency and Species Composition. During the higher rainfall season, the sampling effort was 175 days/trap, resulting in 286 independent records of 13 species, ten families,

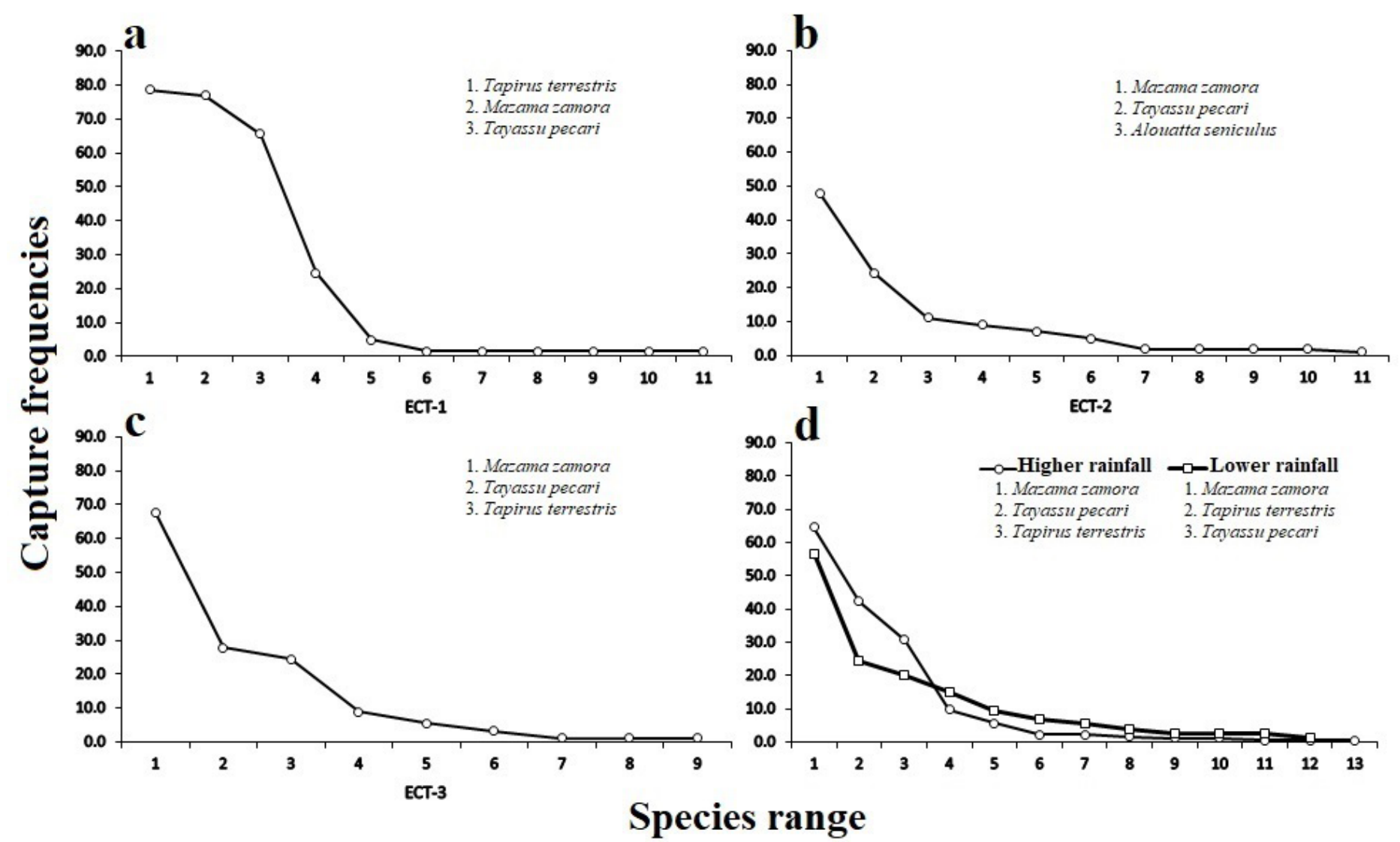

Figure 2. Range-abundance curves (Whittaker's plots) with capture frequencies for the mineral licks a) ECT-1. b) ECT-2. c) ECT-3. d) Seasons of higher and lower rainfall. 


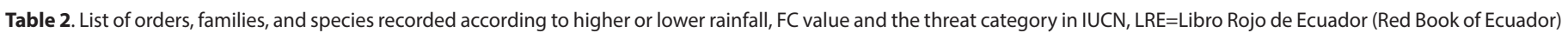
and CITES.

\begin{tabular}{|c|c|c|c|c|c|c|c|c|c|c|c|}
\hline \multirow{3}{*}{ List } & \multicolumn{4}{|c|}{ Higher rainfall } & \multirow{2}{*}{\multicolumn{2}{|c|}{$\frac{\text { Lower rainfall }}{\text { Nov-Dec }}$}} & \multirow{2}{*}{\multicolumn{2}{|c|}{ Total }} & \multirow{3}{*}{ IUCN } & \multirow{3}{*}{ LRE } & \multirow{3}{*}{ CITES } \\
\hline & \multicolumn{2}{|c|}{ Feb-Mar } & \multicolumn{2}{|c|}{ Jun-Jul } & & & & & & & \\
\hline & No. Rec. & FC & No. Rec. & FC & No. Rec. & FC & No. Rec. & FC & & & \\
\hline \multicolumn{12}{|l|}{ ARTIODACTYLA } \\
\hline \multicolumn{12}{|l|}{ Cervidae } \\
\hline Mazama zamora & 55 & 54.5 & 58 & 78.4 & 42 & 56.8 & 155 & 62.2 & $\mathrm{DD}$ & NT & * \\
\hline Mazama murelia & 0 & 0.0 & 4 & 5.4 & 2 & 2.7 & 6 & 2.4 & LC & NT & * \\
\hline \multicolumn{12}{|l|}{ Tayassuidae } \\
\hline Tayassu pecari & 47 & 46.5 & 27 & 36.5 & 15 & 20.3 & 89 & 35.7 & VU & $\mathrm{CR}$ & II \\
\hline Pecari tajacu & 1 & 1.0 & 16 & 21.6 & 3 & 4.1 & 20 & 8.0 & LC & NT & ॥ \\
\hline \multicolumn{12}{|l|}{ CARNIVORA } \\
\hline \multicolumn{12}{|l|}{ Felidae } \\
\hline Leopardus pardalis & 0 & 0.0 & 3 & 4.1 & 7 & 9.5 & 10 & 4.0 & LC & NT & I \\
\hline \multicolumn{12}{|l|}{ CINGULATA } \\
\hline \multicolumn{12}{|l|}{ Dasypodidae } \\
\hline Dasypus pastasae & 0 & 0.0 & 0 & 0.0 & 2 & 2.7 & 2 & 0.8 & LC & $\mathrm{DD}$ & * \\
\hline Dasypus novemcinctus & 8 & 7.9 & 2 & 2.7 & 1 & 1.4 & 11 & 4.4 & LC & $\mathrm{LC}$ & * \\
\hline \multicolumn{12}{|l|}{ PERISSODACTYLA } \\
\hline \multicolumn{12}{|l|}{ Tapiridae } \\
\hline Tapirus terrestris & 35 & 34.7 & 19 & 25.7 & 18 & 24.3 & 72 & 28.9 & VU & EN & ॥ \\
\hline \multicolumn{12}{|l|}{ PILOSA } \\
\hline \multicolumn{12}{|l|}{ Myrmecophagidae } \\
\hline Tamandua tetradactyla & 1 & 1.0 & 0 & 0.0 & 0 & 0.0 & 1 & 0.4 & $\mathrm{LC}$ & LC & * \\
\hline \multicolumn{12}{|l|}{ PRIMATES } \\
\hline \multicolumn{12}{|l|}{ Atelidae } \\
\hline Alouatta seniculus & 0 & 0.0 & 0 & 0.0 & 11 & 14.9 & 11 & 4.4 & LC & LC & II \\
\hline Ateles belzebuth & 0 & 0.0 & 0 & 0.0 & 2 & 2.7 & 2 & 0.8 & EN & EN & ॥ \\
\hline \multicolumn{12}{|l|}{ Cebidae } \\
\hline Cebus yuracus & 1 & 1.0 & 0 & 0.0 & 0 & 0.0 & 1 & 0.4 & LC & NT & * \\
\hline \multicolumn{12}{|l|}{ RODENTIA } \\
\hline \multicolumn{12}{|l|}{ Dasyproctidae } \\
\hline Myoprocta pratti & 0 & 0.0 & 1 & 1.4 & 0 & 0.0 & 1 & 0.4 & $\mathrm{LC}$ & $\mathrm{LC}$ & $*$ \\
\hline Dasyprocta fuliginosa & 1 & 1.0 & 1 & 1.4 & 4 & 5.4 & 6 & 2.4 & $\mathrm{LC}$ & $\mathrm{LC}$ & * \\
\hline Cuniculidae & & & & & & & & & & & \\
\hline Cuniculus paca & 4 & 4.0 & 0 & 0.0 & 5 & 6.8 & 9 & 3.6 & LC & NT & III \\
\hline Erethizontidae & & & & & & & & & & & \\
\hline Coendou prehensilis & 1 & 1.0 & 1 & 1.4 & 0 & 0.0 & 2 & 0.8 & LC & $\mathrm{DD}$ & * \\
\hline
\end{tabular}

and seven orders. In the season of lower rainfall, the sampling effort was 74 camera trap days, yielding 112 independent records of 12 species in eight families and six orders.

Between the two seasons, the rarefaction analysis interpolating to the lowest number of independent records (112) revealed that ten species were recorded during the higher rainfall season and 12 in the lower rainfall season. The $95 \%$ confidence intervals overlapped, so no significant difference in species richness from climatic seasonality was observed (Figure 3).

In the higher rainfall season, the most frequent species were $M$. zamora (113 records, $\mathrm{FC}=64.6)$, $T$. pecari $(74$ records, $\mathrm{FC}=42.39$ ), $T$. terrestris (54 records, $\mathrm{FC}=30.9$ ), and $P$. tajacu
(17 records, $\mathrm{FC}=9.7$ ). In the lower rainfall season, the most frequent species were $M$. zamora (42 records, $\mathrm{FC}=56.8$ ), T. terrestris (18 records, $\mathrm{FC}=24.3$ ), T. pecari (15 records, $\mathrm{FC}=20.3$ ), and red howler (Alouatta seniculus; 11 records, $F C=14.9$ ).

When the range-abundance $(F C)$ curves are compared between the two seasons, $M$. zamora is the predominant species in both seasons, followed by $T$. pecari and T. terrestris. These were the most abundant species that were observed most frequently in mineral licks (Figure 2).

Similarity. ECT-1 (C. albifrons, T. tetradactyla, and $M$. pratti) and ECT-2 (C. prehensilis, A. seniculus, and A. belzebuth) showed three species that were not observed in any other mineral lick; ECT-3 had no unique species. Accord- 
ing to the Jaccard similarity index, stations ECT-1 and ECT-2 shared $37.5 \%$ of the recorded species. For their part, ECT-1 and ECT-3 shared $53.8 \%$ of species, the same percentage shared by ECT-2 with ECT-3.

The higher rainfall season recorded four unique species (C. yaracus, C. prehensilis, T. tetradactyla, and M. pratti) and the lower rainfall season recorded three unique species (A. seniculus, A. belzebuth, and D. pastasae). Altogether, the two climatic seasons yielded $56.3 \%$ of species similarity, according to the Jaccard index.

\section{Discussion}

Fauna Recorded in Mineral licks. According to the richness estimators Chao1 $(S=16.8)$ and ACE $(S=18.7)$, a considerable sample was obtained to determine the richness of species visiting mineral licks. However, species richness would probably increase with a higher sampling effort as the species accumulation curve $\left(\mathrm{S}_{\text {obs }}=16\right)$ shows no asymptotic trend. Whittaker's plots are similar for the three mineral licks, showing equal species capture frequencies and the same dominant species (Figure 2). On the other hand, rarefaction

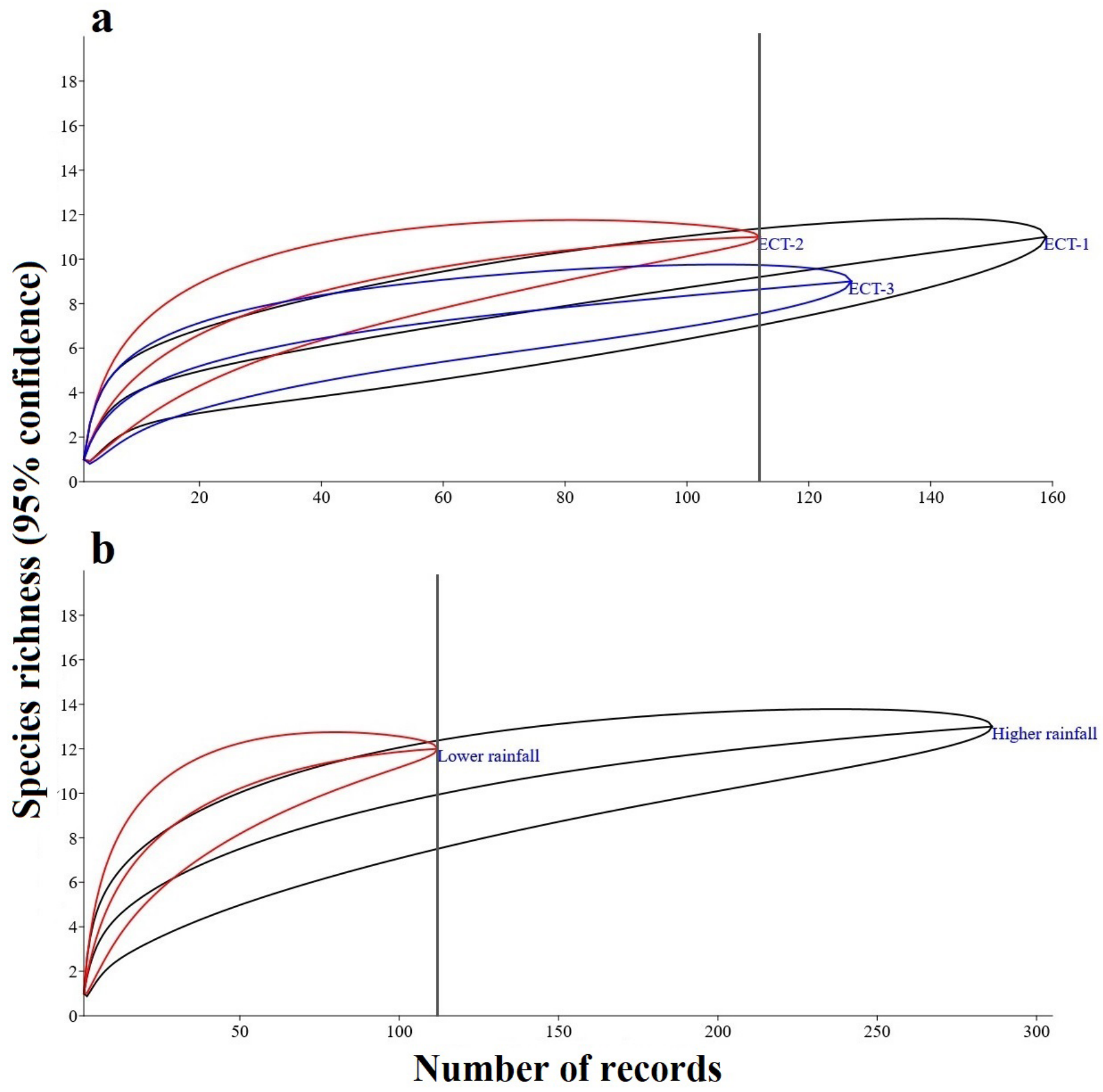

Figure 3. Rarefaction curves based on species richness for a standard sample of 112 independent records in a) ECT-1. ECT-2. ECT-3 mineral licks. b) Seasons of higher and lower rainfall, with a $95 \%$ confidence interval in both cases. 
curves evidenced a non-significant difference in the species recorded in the three mineral licks (Figure 3), thus stressing the importance of conserving mineral licks as sources of mineral supplements for the visiting fauna. As in previous studies carried out in the Neotropics (Tobler et al. 2009; Blake et al. 2011; Blake et al. 2013), the red brocket, collared peccary, white-lipped peccary, and South American tapir were the species most frequently recorded in these habitats, also being commonly hunted (Blake et al. 2013).

Comparing the capture frequencies of four species with those obtained by Blake et al. (2013) in two locations -one disturbed from the proximity of a road and under hunting pressure (YRS) and the other being hard to access and under minimum hunting pressure (TBS)-, the capture frequencies in the present study are in between those observed in TBS and YRS (Table 3); the exception was T. pecari, which showed a higher capture frequency. It is worth mentioning that this was one of the most heavily hunted species in the Añangu community area some 20 years ago (Suárez and Zapata 2019). For this reason, we assume that in the mineral licks included in this study, animal populations that were previously overhunted may be undergoing a recovery process; this deserves to be further explored in future research.

Other recorded species, such as the nine-banded armadillo (Dasypus novemcinctus) and the ocelot (Leopardus pardalis), are rare in mineral licks (Blake et al. 2011), but both have been recorded more frequently along trails (Blake et al. 2012, 2013; P. Macas-Pogo, personal observation). Ocelots are usually attracted by bats that visit certain mineral licks and are part of their diet (Tinoco and Camacho 2015; Contreras-Moreno et al. 2019) and have also been seen hunting amphibians (P. Macas-Pogo, personal observation). The red howler (A. seniculus) and the yellow-bellied spider monkey (A. belzebuth) are two of the most hunted primate species (Mena et al. 2000), so much so that their populations have been decimated in some areas of the Yasuní National Park (Franzen 2006). This study recorded these two species only in ECT-2 and with low capture frequencies ( $F C=4.4$ and $\mathrm{FC}=0.8$, respectively), especially the yellow-bellied spider monkey, a frequent visitor to mineral licks (Blake et al. 2010; Link et al. 2011). The black agouti (Dasyprocta fuliginosa) is another species preferred by hunters; this work recorded it at the three study sites. However, compared to data from studies performed by Blake et al. (2011) and Blake et al. (2013), the number of records is minimal, as is the number of other small species; this could be related to the sampling

Table 3. Comparison of capture frequencies $(F C)$ of four species reported by Blake et al. (2013) versus the figures obtained in the present study.

\begin{tabular}{lrrr}
\hline \multirow{2}{*}{ Species } & \multicolumn{2}{c}{ Blake et al. 2013 } & \multicolumn{2}{c}{ Present study } \\
& TBS (FC) & YRS (FC) & ECT-Total (FC) \\
\hline Mazama zamora & 211.2 & 57.7 & 62.2 \\
Tapirus terrestris & 37.1 & 25.5 & 28.9 \\
Pecari tajacu & 48.2 & 5.5 & 8 \\
Tayassu pecari & 28.1 & 0 & 37.5 \\
\hline
\end{tabular}

effort or even to the position of camera traps at the time of installation.

Climatic Seasonality. Several research studies on geophagy indicate that climatic seasonality influences the use of mineral licks (Jones and Hanson 1985; Atwood and Weeks 2003; Link et al. 2012) and that animals prefer visiting these sites on sunny days with no mist, wind, or rain (Brightsmith 2004). By contrast, according to Link et al. (2011), they display reduced activity in days of heavy rains. However, the rarefaction analysis indicated no significant differences between climatic seasons for the species recorded. The species composition was similar in the two seasons, with a Jaccard index higher than 0.5 (56.3\% similarity); the red brocket, white-lipped peccary, and South American tapir were the dominant species in both seasons. The slopes of Whittaker's plots are steep, suggesting a low evenness of species (Figure 2).

The species recorded only in the lower rainfall season and those captured exclusively in the higher rainfall season with one or two records are insufficient to determine whether the use of mineral licks is related to the season of the year. Factors such as water accumulation in mineral licks are attractive to some individuals (Link et al.2011). The consumption of fruits, seeds, or plants that produce secondary metabolites varies seasonally (Brightsmith 2004; Voigt et al. 2007) and induces mammals to search for mineral salts.

For the inhabitants of Añangu, based on a self-mandated internal regulation, the discontinuation of wildlife overhunting and, most importantly, wildlife trafficking, has yielded favorable results since today the fauna that can be observed is attractive for tourists visiting the area. A central factor in preventing wildlife trafficking has been that there are neither main roads nor alternate roads near mineral lick sites, and thus the hunting pressure has dropped significantly. This contrasts with areas crossed by the Maxus road where, according to Suárez and Zapata (2018), wildlife has been severely affected and the indirect effects of roads and the oil industry have been underestimated. Besides, excess hunting by the Waorani has led to the local extinction of the hunted species (Mena et al. 2000; Franzen 2006; Espinosa et al. 2014; Blake et al. 2013).

In conclusion, the results presented herein evidence the richness of mammalian species that use these mineral licks as an important source of minerals, which are undoubtedly essential for the normal development of organisms. As mentioned earlier, there is no marked climatic seasonality in this region; therefore, this factor is not a driver for peccaries, brockets, and tapirs when visiting a mineral lick since they were recorded in the three mineral licks over the three sampling periods studied, being the species with the highest capture frequencies. Besides, we recorded species unique to two of the three mineral licks to each climatic season. Therefore, the use of a given mineral lick may also be determined by home range, the particular behavior of each species, hunting pressure, or other factors that deserve further investigation in future research. 
Mineral licks might be an important resource for local human populations if these are given proper use as subsistence hunting sites or even as sites for wildlife-watching tourism. It is evident that the sustainable practices adopted by the Añangu community support the sustainable management of these sites, making a positive contribution to the conservation of biodiversity in the Yasuní National Park. These mineral licks represent areas that should be valued for their role in the ecosystem, mainly in the diet of the fauna using them. Additional studies are needed to advance our understanding of their characteristics and contributions to forest dynamics. In addition to continuing the application of sustainable tourism practices, the local community should be advised to implement clear guidelines setting restrictions, visiting hours, and behavior of visitors of mammalian mineral licks to ensure their protection.

\section{Acknowledgments}

The authors wish to thank the Kichwa Añangu community for providing support and guidance to enter their area and for assistance in the installation of camera traps. To M. Jipa, president of the community, for his support throughout the study. Thanks also to the park rangers of the Ministry of Environment, Water and Ecological Transition of Ecuador, who assisted in the review of camera traps and checked them for proper operation throughout the study; our respect and admiration to all park rangers who work hard every day in the conservation of the Yasuní National Park. Special thanks to the reviewers who helped enrich previous versions of this document. We also thank the Fondo Ambiental Sostenible for its valuable contribution in the publication of this article and the Government of Ecuador through the Programa de Reparación Ambiental y Social for allowing us to carry out this study and having provided us with the materials, equipment, and logistic resources to achieve the desired objective. María Elena Sánchez-Salazar translated the manuscript into English.

\section{Literature cited}

Albuja, L., A. Almendáriz, R. Barriga, L. D. Montalvo, F. Cáceres, And J. L. Román. 2012. Fauna de Vertebrados del Ecuador. Instituto de Ciencias Biológicas. Escuela Politécnica Nacional. Quito, Ecuador.

Atwood, T. C., And H. P. Weeks. 2003. Sex-specific patterns of mineral lick preference in white-tailed deer. Northeastern Naturalist 10:409-414.

Bass, M. S., M. Finer, C. N. Jenkins, H. Kreft, D. F.Cisneros-Heredia, S. F. McCracken, N. C. A. Pitman, P. H. English, K. Swing, G. Villa, A. Di Fiore, C. C. Voigt, And T. H. Kunz. 2010. Global Conservation Significance of Ecuador's Yasuní National Park. Plos One 5: e8767.

Benitez-López, A., R. Alkemade, A. M. Schipper, D. J. Ingram, P. A. Verweis, J. A. J. Eikelboom, AND M. A. J. Huijbregts. 2017. The impact of hunting on tropical mammal and bird. Science 356:180-183.

Blake, J. G., J. Guerra, D. Mosquera, R. Torres, B. A. Loiselle, and D. Roмо. 2010. Use of mineral licks by white-bellied spider monkeys (Ateles belzebuth) and red howler monkeys (Alouatta seniculus) in eastern Ecuador. International Journal of Primatology 31:471-483.

Blake, J. G., D. Mosquera, J. Guerra, B. A. Loiselle, D. Romo, and K. Swing. 2011. Mineral licks as diversity hotspots in lowland forest of eastern Ecuador. Diversity 3:217-234.

BLAKE, J. G., D. MOSQuera, AND J. SALVADOR. 2013. Use of mineral licks by mammals and birds in hunted and non-hunted areas of Yasuní National Park, Ecuador. Animal. Conservation 16:430-437.

Blake, J. G., D. Mosquera, B. A. Loiselle, K. Swing, J. Guerra, and D. Roмо. 2012. Temporal activity patterns of terrestrial mammals in lowland rainforest of eastern, Ecuador. Ecotropica 137:137-146.

Blake, J. G., J. Guerra, D. Mosquera, R. Torres, B. A. Loiselle, and D. Rомо. 2010. Use of mineral licks by white-bellied spider monkeys (Ateles belzebuth) and red howler monkeys (Alouatta seniculus) in eastern Ecuador. International Journal of Primatology 31:471-483.

Bravo, A., K. E. Harms, R. S. Stevens, and L. H. Emmons. 2008. Collpas: Activity Hotspots for Frugivorous Bats (Phyllostomidae) in the Peruvian Amazon. Biotropica 40:203-210.

BRIGHTSMITH, D. J. 2004. Effects of weather on parrot geophagy in Tambopata, Peru. The Wilson Bulletin 116:134-145.

Colwell, R. K., AND J. A. Coddington. 1994. Estimating terrestrial biodiversity through extrapolation. Philosophical Transactions of the Royal Society of London 345:101-118

Colwell, R. K. 2013. EstimateS v9.1.0. Statistical estimation of species richness and shared species from samples. Program distributed by the author.

Colwell, R. K., A. Chao, and J. Gotell. 2012. Models and estimators linking individual-based and sample-based rarefaction, extrapolation and comparison of assemblages. Journal of Plant Ecology 5:3-21.

Contreras-Moreno, F. M., D. Simá-Pantí, J. A. Zúniga-Morales, C. Coutiño-Cal y Mayor, J. Y. Borges-Zapata, and I. Serrano-MacGREGOR. 2019. Registro fotográfico de un murciélago capturado por Leopardus pardalis (Carnivora: Felidae) en la Reserva de la Biosfera Calakmul, México. Mammalogy Notes 5:6-9

Davies, A. G., And I. C. Bailuie. 1988. Soil eating by red leafmonkeys (Presbytis rubicunda) in Sabah, Northern Borneo. Biotropica 20:252-258.

Diamond, J., D. Bishop, AND J. D. Gilardi. 2008. Geophagy in New Guinea birds. International journal of avian science 141:181-193.

Emmons, L. H. and N. M. Stark. 1979. Elemental composition of a natural mineral lick in Amazonia. Biotropica 4:311-313.

Espinosa, S., AND J. Salvador. 2017. Hunters' landscape accessibility and daily activity of ungulates in Yasuní Biosphere Reserve, Ecuador. Therya 8:45-52

Espinosa, S., L. C. Branch, and R. Cueva. 2014. Road development and the geography of hunting by an Amazonian indigenous group: Consequences for wildlife conservation. Plos One 9:1-21. Franzen, M. 2006. Evaluating the sustainability of hunting: a comparison of harvest profiles across three Huaorani communities. Environmental Conservation 33:36-45.

Gilardi, J. D., S. S. Duffey, C. A. Munn, AND L. A. Tell. 1999. Biochemical functions in geophagy in parrots: detoxification of dietary toxins and cytoprotective effects. Journal of Chemical Ecology 25:897-922. 
Hammer, O., D. Harper, and P. Ryan. 2001. PAST: Paleontological statistics software package for education and data analysis. Palenteología electrónica 4:9.

IzawA, K. 1993. Soil eating by Alouatta and Ateles. International Journal of Primatology 14:229-242.

Jones, R. L., And H. C. Hanson. 1985. Mineral licks, geophagy and biogeochemistry in North American ungulates. lowa State University Press. Ames, U.S.A.

KLAus, G., AND B. Schmid. 1998. Geophagy at natural licks and mammal ecology: a review. Mammalia 62:481-497.

KreBs, C. J. 1989. Ecological methodology. Harper and Row Publishers Inc. New York, U.S.A.

KREULen, D. A. 1985. Lick use by large herbivores: a review of benefits and banes of soil consumption. Mammal Review 15:107-123.

Krishnamani, R., And W. C. Mahaney. 2000. Geophagy among primates: Adaptive significance and ecological consequences. Animal Behaviour 59:899-915.

Licona, M., R. McCleery, B. Collier, D. J. Brightsmith, ANd R. LoPEZ. 2011. Using ungulate occurrence to evaluate community-based conservation within a biosphere reserve model. Animal Conservation 14:206-214.

Link, A., A. Di Fiore, N. Galvis, And E. Fleming. 2012. Patterns of mineral lick visitation by lowland tapir (Tapirus terrestris) and lowland paca (Cuniculus paca) in a western amazonian rainforest in Ecuador. Mastozoología Neotropical 19:63-70.

Link, A., N. Galvis, E. Fleming, And A. Di Fiore. 2011. Patterns of mineral lick visitation by spider monkeys and howler monkeys in Amazonia: are licks perceived as risky areas? American Journal of Primatology 73:386-396.

Lizcano, D. J., ANd J. Cavelier. 2004. Chemical characteristics of salt licks and feeding habits of mountain tapir (Tapirus pinchaque) in the Central Andes of Colombia. Maztozoología Neotropical 11:193-201.

Magurran, A. E. 2004. Measuring biological diversity. Oxford, England.

Mahaney, W. C., M. W. Milner, S. Aufreiter, R. G. V. Hancock, R. Wrangham, And S. Campbell. 2005. Soils consumed by chimpanzees of the Kanyawara community in the Kibale forest, Uganda. International Journal of Primatology 26:1375-1398.

Mena, P., J. Stallings, J. Regalado, and R. Cueva. 2000. The sustainability of current hunting practices by the Huaorani. Hunting for sustainability in tropical forests 57-78.

Montenegro, O. L. 2004. Natural licks as keystone resources for wildlife and people in Amazonia. PhD Dissertation, University of Florida. Gainesville, U.S.A.

Moreno, C. E. 2001. Métodos para medir la biodiversidad. Manuales y Tesis SEA. Sociedad Entomológica Aragonesa Ed. Madrid, España.

Pitman, N. 2000. A large-scale inventory of two Amazonian tree communities. Ph.D. thesis. Department of Botany, Duke University. Durham, U.S.A.

Renkert, S. R. 2019. Community-owned tourism and degrowth: a case study in the Kichwa Añangu community. Journal of Sustainable Tourism 27:1893-1908.

Setz, E. Z. F., J. Enzweiler, V. N. Solferini, M. P. Amendola, And R. S. Berton. 1999. Geophagy in the golden-faced saki mon- key (Pithecia pithecia chrysocephala) in the Central Amazon. Journal of Zoology 247:91-103.

Suárez, E., M. Morales, R. Cueva, U. V. Bucheli, G. Zapata-Ríos, E. Toral, J. Torres, W. Prado, and V. J. Olalla. 2009. Oil industry, wild meat trade and roads: indirect effects of oil extraction activities in a protected area in north-eastern Ecuador. Animal Conservation 12:364-373.

SuÁreZ, E., AND G. Zapata-Ríos. 2019. Managing subsistence hunting in the changing landscape of Neotropical rain forests. Biotropica 51:282-287.

Tinoco, N., AND M. A. CAmacho. 2015. Records of bats predated by Leopardus pardalis (Carnivora: Felidae) in eastern Ecuador. Revista Biodiversidad Neotropical 5:105-110.

Tobler, M. W., S. E. Carrillo-Percastegui, and G. Powell. 2009. Habitat use, activity patterns and use of mineral licks by five species of ungulate in south-eastern Peru. Journal of Tropical Ecology 25:261-270.

Tracy, B. F., AND J. McNaughton. 1995. Elemental analysis of mineral lick soils from the Serengueti National Park, the Konza Prairie and the Yellowstone National Park. Ecogeography 18:91-94.

Unesco. 2010. Atlas pluviométrico del Ecuador. Programa hidrológico internacional de la UNESCO para América Latina y el Caribe, Jonathan Cedeño, María Concepción Donoso, Documentos Técnicos del PHI-LAC, N²1. Ecuador. 2010.

Voigt, C. C., D. K. N. Dechmann, J. Bender, B. J. Rinehart, R. H. Michener, AND T. H. Kunz. 2007. Mineral licks attract neotropical seed-dispersing bats. Research Letters in Ecology 2007:4.

Associated editor: Eduardo Mendoza

Submitted: November 6, 2020; Reviewed: January 8, 2021.

Accepted: August15, 2021; Published on line: September 17, 2021. 
608 THERYA Vol. 12 (3): 599-607 